\title{
Reflection on the interactions between social determinants of food insecurity and health problems in an urban context
}

\author{
Reflexão sobre as interacções entre determinantes sociais na insegurança alimentar e os \\ problemas de saúde em contexto urbano
}

\author{
Isabel Craveiro ${ }^{1,2}$, Daniela Alves ${ }^{1}$ \\ ${ }^{1}$ Instituto de Higiene e Medicina Tropical, IHMT, Universidade Nova de Lisboa, UNL, Lisboa, Portugal \\ ${ }^{2}$ Global Health and Tropical Medicine, Instituto de Higiene e Medicina Tropical, IHMT, Universidade Nova de Lisboa, \\ UNL, Lisboa, Portugal \\ e-mail: isabelc@ihmt.unl.pt
}

\begin{abstract}
The interdependence between social conditions and health conditions are established and the reduction of poverty and promotion of food security are fundamental on the road to better health of populations. Strengthening food security was recognised as one of the cornerstones in the perspective of the social determinants of health.

Food insecurity is a daily reality for hundreds of millions of people worldwide. Despite its more often obvious extreme signs, it is more difficult to identify other signs that are revealed in families that face constraints on access to food.

In urban areas, food insecurity is related to income, but also to access to food, with the possibility of these situations in urban areas generating another cause of poverty increasing related health problems.

In this brief review we seek to reflect on the challenges in terms of social determinants of food security and their interactions with health problems in rapid urbanization contexts, focusing on the African context.
\end{abstract}

Keywords: social determinants of health; food insecurity; urban context; low-income countries

\section{Resumo}

A interdependência entre as condições sociais e as condições de saúde está demonstrada sendo a redução da pobreza e a promoção da segurança alimentar peças basilares no caminho para uma melhor saúde das populações. $\mathrm{O}$ fortalecimento da segurança alimentar constituiu-se como um dos eixos fundamentais na perspectiva dos determinantes sociais de saúde.

A insegurança alimentar é uma realidade diária para centenas de milhões de pessoas em todo o mundo. Apesar de as suas manifestações mais extremas serem muitas vezes óbvias, é mais difícil identificar outras que se manifestam em famílias que enfrentam restrições no acesso aos alimentos.

Em áreas urbanas a insegurança alimentar está relacionada com os rendimentos, mas também com a acessibilidade aos alimentos, com a possibilidade dessas situações em áreas urbanas funcionarem como mais uma causa de pobreza, acentuando os problemas de saúde correlacionados.

Nesta breve revisão procuramos reflectir sobre os desafios colocados em termos de determinantes sociais da segurança alimentar e as suas interacções com problemas de saúde em contextos de rápida urbanização com foco no contexto africano.

Palavras-Chave: determinantes sociais de saúde; insegurança alimentar; contextos urbanos; países de baixa renda 


\section{Social Determinants of Health}

The social determinants of health (SDH) are related to the conditions in which people are born, grow, work and live, the broader set of circumstances and systems that affect the conditions of daily life. Among them, the political and economic systems and development agendas include social norms, social policies and political systems ${ }^{[1]}$.

According to Buss and Pellegrini Filho ${ }^{[2]}$, "the numerous social determinants of health definitions reveal the concept currently quite widespread that the conditions of life and work of individuals and population groups are related to their health situation".

Health becomes an expression of the social question as it results from a set of determining factors and conditions, such as food, housing, sanitation, environment, employment and income, education, transport, leisure and access to fundamental goods and services ${ }^{[3]}$.

One of the most popular social determinants of health models is the Dahlgren and Whitehead ${ }^{[4]}$, which is represented in layers (Figure 1). The third level is related to the conduct of policies on the material and psychosocial conditions in which people live and work, ensuring better access to clean water, sanitation, adequate housing, healthy and nutritious food, safe employment, healthy work environments, quality health and education services, and others ${ }^{[2]}$.

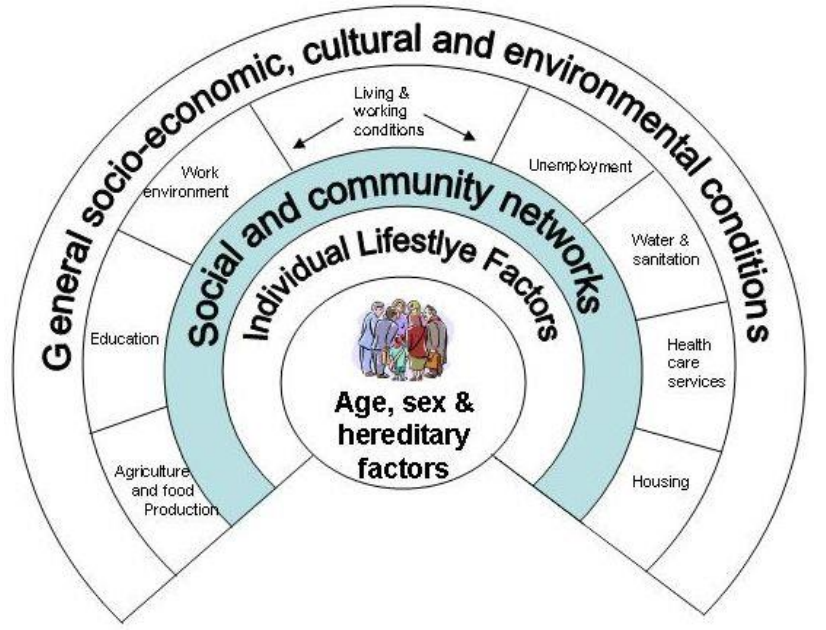

Figure 1 - Social determinants of health model Dahlgren and Whitehead

\section{Determinantes sociais da saúde}

Os determinantes sociais da saúde (SDH) estão relacionados com as condições em que as pessoas nascem, crescem, trabalham, vivem, o conjunto mais vasto de circunstâncias e sistemas que condicionam as condições de vida diária. Entre eles, incluem-se os sistemas político e económico e as agendas de desenvolvimento, as normas sociais, as políticas sociais e os sistemas políticos $^{[1]}$.

Segundo Buss e Pellegrini Filho ${ }^{[2]}$, "as diversas definições de determinantes sociais de saúde expressam o conceito atualmente bastante generalizado de que as condições de vida e trabalho dos indivíduos e de grupos da população estão relacionadas com sua situação de saúde".

A saúde torna-se uma expressão da questão social na medida em que resulta de um conjunto de factores determinantes e condicionantes, como alimentação, habitação, saneamento básico, ambiente, trabalho e renda, educação, transporte, lazer e acesso aos bens e serviços essenciais $^{[3]}$.

Um dos mais conhecidos modelos de determinantes sociais de saúde é o de Dahlgren e Whitehead ${ }^{[4]}$, que está representado em camadas (Figura 1), em que o terceiro nível está relacionado com a actuação das políticas sobre as condições materiais e psicossociais nas quais as pessoas vivem e trabalham, assegurando melhor acesso à água potável, esgotos, habitação adequada, alimentos saudáveis e nutritivos, emprego seguro, ambientes de trabalho saudáveis, serviços de saúde e de educação de qualidade e outros ${ }^{[2]}$.

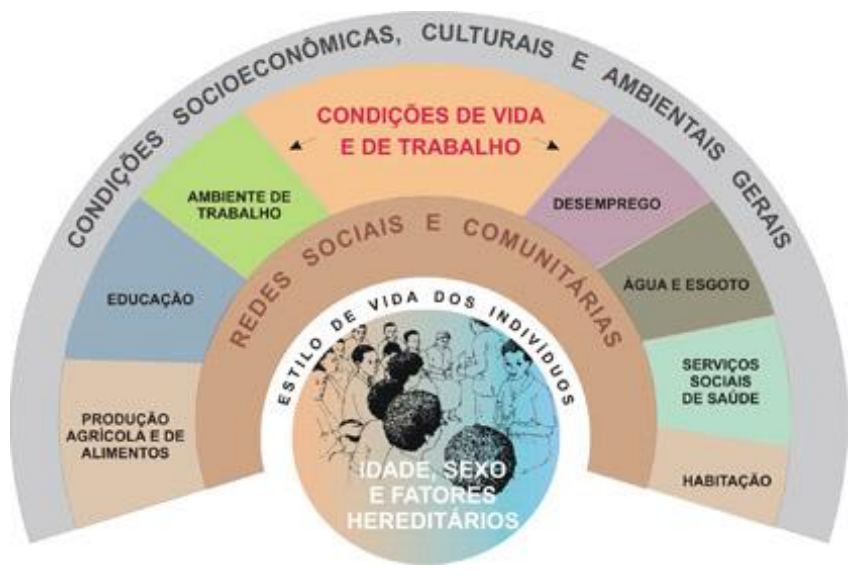

Figura 1 - Modelo de determinantes sociais de saúde de Dahlgren e Whitehead 
Socio-economic factors have for a long time been identified as the main determinants of nutritional status ${ }^{[5]}$ and are therefore very important to identify policies that will reduce the nutritional deficiency.

The relevance of addressing the social determinants of food insecurity is because it is recognized that the evidence base is still limited, especially with regard to issues of household food insecurity ${ }^{[6]}$.

Regarding the determinants of household food insecurity, Harris and colleagues ${ }^{[6]}$ following the recognition of the World Food Summit in 1996 - reconfirmed in $2002^{[7]}$ - identify three main dimensions: 1) food availability; 2) access to food and 3) use of food. In fact, these are also the key determinants ${ }^{[8]}$ of household food security in the urban context.

It has been long well-known ${ }^{[9]}$ that the main determinant of food insecurity is the lack of financial resources, and one of the main ways of societies solve the needs of citizens is through active public policies to reduce poverty and protect most vulnerable non-poor ${ }^{[10]}$.

Social determinants of health are potentially transformed by evidence-based action. One possibility is to focus on health education and empowerment of the people struggling for social rights and health, and focus on policies which are consistent with improvements in living conditions, especially in an urban context.

Understanding the determinants and factors that cause food insecurity at the moment is essential to reduce it in the long run ${ }^{[11-14]}$.

\section{Food and Nutrition Security in the urban context}

Food security is attained when all people have physical, social and economic access to sufficient and nutritious food to ensure a healthy life to anyone. In turn, food insecurity depends on climatic factors, limited access to food and especially low income ${ }^{[7]}$. Food insecurity exists when there is limited or uncertain access to nutritionally adequate and safe foods or limited or uncertain ability to acquire food in a socially acceptable manner. The determinants related to the availability, access and use are hierarchical in nature, that is, the availability of food is necessary but not sufficient for access, and access is necessary, but not sufficient for use. Additionally, a fourth concept has been increasingly accepted
Os factores socioeconómicos têm sido identificados desde há muito tempo como os principais determinantes da situação nutricional ${ }^{[5]}$, sendo por isso muito importante a identificação de políticas que permitam reduzir a deficiência nutricional.

A pertinência de abordar os determinantes sociais da insegurança alimentar advém do facto de ser um tema em que é reconhecido existir ainda uma limitada base de evidência, sobretudo no que concerne às questões da insegurança alimentar das famílias ${ }^{[6]}$.

$\mathrm{Na}$ questão concreta dos determinantes da insegurança alimentar das famílias, Harris e colegas ${ }^{[6]}$, na esteira do reconhecimento da World Food Summit em 1996 e reconfirmada em $2002^{[7]}$, identificam as seguintes dimensões: 1) disponibilidade alimentar; 2) acesso aos alimentos e 3) utilização dos alimentos. Na verdade, estes são também os determinantes chave ${ }^{[8]}$ da segurança alimentar das famílias em contexto urbano.

Sabendo-se desde há muito ${ }^{[9]}$ que o principal determinante da insegurança alimentar é a falta de recursos financeiros, uma das principais formas de as sociedades resolverem as necessidades dos cidadãos é através de políticas públicas activas para diminuir a pobreza e proteger os mais vulneráveis não pobres ${ }^{[10]}$.

Os determinantes sociais de saúde são potencialmente alterados pela acção baseada em evidência. Uma das possibilidades é a aposta na educação para a saúde e emponderamento da população lutando para que os direitos sociais e de saúde prevaleçam e as políticas sejam concordantes com melhorias das condições de vida, nomeadamente em contexto urbano.

A compreensão dos determinantes e dos factores que causam a insegurança alimentar no momento presente são essenciais para a redução da mesma a longo pra$\mathrm{ZO}^{[11-14]}$

\section{Segurança Alimentar e Nutricional em contexto urbano}

A segurança alimentar é alcançada quando todas as pessoas têm acesso físico, social e económico a alimentos suficientes, em todos os momentos, e nutritivos para garantir uma vida saudável a qualquer pessoa. Por sua vez, a insegurança alimentar depende de factores climáticos, do acesso limitado aos alimentos e principalmente dos baixos rendimentos ${ }^{[7]}$. A insegurança alimentar existe quando há um acesso limitado ou incerto a alimentos nutricionalmente adequados e seguros ou uma capacidade limitada ou incerta para adquirir alimentos de uma forma socialmente aceitável.

Os determinantes relacionados com a disponibilidade, o acesso e a utilização são de natureza hierárquica, isto é, a disponibilidade de alimentos é necessária mas não 
with regard to risk, such as climate change, conflict, job loss, and epidemic diseases that can damage any of the first three determinants. In this sense, risk is a crosscutting issue that affects all areas of food insecurity ${ }^{[15]}$. In 2011 the Food and Agriculture Organization and the World Health Organization (FAO / WHO), reconfirmed the concept of food security, defining it as the process of "ensuring continued access for all people to sufficient quantities of safe food ensuring a proper diet; achieve and maintain the welfare of health and nutrition of all people; promote a process of socially and environmentally sustainable development, contributing to an improvement in nutrition and health, eliminating epidemics and deaths by famine"[16]. When there is a violation of this right, there are situations of food insecurity ${ }^{[17]}$

The food insecurity situations are intertwined with social and financial conditions of households, with the phenomenon of poverty mentioned as one of the most important dimensions ${ }^{[18]}$.

There are different stages of severity in terms of food insecurity, starting with not being able to buy and eat what you like due to restrictions in terms of available income. This comprises food quality issues, including variety, safety and nutrients. The next step involves a decrease in the amount of food ingested and attempts to make the food last until there is money to buy more. The decrease in the amount of food ingested can then lead to physical sensation of hunger. Finally, the most severe stage is the complete absence of food intake ${ }^{[19,20]}$ Food security is considered fundamental in the socioeconomic development process of any country. Food insecurity varies from country to country and is strongly related to household income level ${ }^{[20]}$.

A positive relationship was also identified between 1) available income in families, and 2) increased education of its members and feeding and health conditions: 1) Family income, due to the impact on food availability, environmental quality and access to basic services such as sanitation and health care; 2) Education of household members, especially the mother's education, impacts through the more or less efficient use (from the child care point of view) of income and public servic$\mathrm{es}^{[17]}$.

Urbanization processes are interrelated with the nutrition transition, particularly because access to food of low nutritional quality at low prices is easier, affecting eating patterns, and enhancing the increase of noncommunicable diseases. Moreover, this type of food is normally rich in complex carbohydrates, fat, sugar, cholesterol and low in fibre and vitamins ${ }^{[21,22]}$.

One of the main issues of food insecurity in urban context relates to the fact that urban residents have to buy suficiente para o acesso, e o acesso é necessário, mas não suficiente para a utilização. Adicionalmente, um quarto conceito é cada vez mais aceite, que diz respeito aos riscos, tais como alterações climáticas, conflitos, perda de emprego, e doenças epidémicas que podem prejudicar qualquer um dos três primeiros determinantes. Nesse sentido, o risco representa uma questão transversal que afecta todos os domínios do quadro de insegurança alimentar ${ }^{[15]}$

Em 2011 a Food and Agriculture Organization e a World Health Organization (FAO/WHO), vêm reconfirmar o conceito de segurança alimentar, definindo-a como o processo de "garantir o acesso continuado para todas as pessoas a quantidades suficientes de alimentos seguros que lhes assegurem uma dieta adequada; atingir e manter o bem-estar de saúde e nutricional de todas as pessoas; promover um processo de desenvolvimento socialmente e ambientalmente sustentável, que contribua para uma melhoria na nutrição e na saúde, eliminando as epidemias e as mortes pela fome"[16]. Quando se verifica a violação deste direito, são geradas as situações de insegurança alimentar ${ }^{[17]}$

As situações de insegurança alimentar estão interligadas com as condições sociais e capacidades financeiras dos agregados familiares, sendo mesmo apontadas como uma das dimensões mais importantes do fenómeno da pobreza ${ }^{[18]}$.

Existem diferentes estágios de gravidade em termos de insegurança alimentar, começando com não ser capaz de comprar e comer o que gostaria devido a restrições em termos de rendimento disponível. O que inclui questões de qualidade dos alimentos, nomeadamente a variedade, segurança e nutrientes. A próxima etapa envolve uma diminuição na quantidade ingerida e tentativas de fazer a comida durar até que haja dinheiro para comprar mais. A diminuição na quantidade de alimentos ingeridos pode então levar à sensação física de fome. Finalmente, a fase mais grave é a completa ausência da ingestão de alimentos ${ }^{[19,20]}$.

A segurança alimentar é considerada basilar no processo de desenvolvimento socioeconómico de qualquer país. A insegurança alimentar varia de país para país e está fortemente relacionada com o nível de rendimentos das famílias ${ }^{[20]}$.

É ainda identificada uma relação positiva entre 1) os rendimentos disponíveis nas famílias e 2) o aumento da escolaridade dos seus membros e as condições de alimentação e saúde da população: 1) O rendimento familiar porque deste depende em grande medida a disponibilidade de alimentos, a qualidade do ambiente e o acesso a serviços essenciais como o saneamento e o acesso aos cuidados de saúde. 2)A escolaridade dos elementos do agregado familiar, sobretudo da escolaridade 
most of their food, unlike what occurs in rural areas, where people can produce their own food ${ }^{[8]}$.

Urban food security is therefore very dependent on monetary conditions, and labour and access to income are key prerequisite issues to ensure food security in these geographic areas. This is intensified by the fact that in many cities in Africa, a considerable percentage of residents depend on informal and occasional activities that only guarantee low, uncertain and irregular income $^{[23]}$. According to Chen ${ }^{[24]}$, informal employment represents half to three-quarters of all non-agricultural employment in low-income countries.

Food availability in an urban area is largely determined by food supply to cities ${ }^{[23]}$.

Studies have shown the specific characteristics of urban food insecurity, with special attention to the need to promote conditions for earning income by households as well as food accessibility in urban context. A spiral of poverty emerges due to food insecurity in urban areas $^{[8]}$.

Rapid urbanization had a significant nutritional impact on many low and middle income countries, contributing to changes in dietary patterns ${ }^{[25]}$.

According to the Food Security and Nutrition Strategy, approved in 2012, the FAO is working with the Community of Portuguese Speaking Countries (CPLP), in order to achieve a "hunger free community." Food insecurity currently affects about 28 million people in the CPLP countries, which have a total of 250 million people ${ }^{[11]}$.

In addition to the aspects of quality and quantity of food, several authors mention other facts, such as psychological distress (e.g., worrying about not having enough to eat) and social and family disruption (e.g., using socially unacceptable ways of obtaining food), which are also important dimensions of food insecurity ${ }^{[26,27]}$. All these examples may have potential impacts (direct and/or indirect) on the health status of populations, and therefore should receive attention from policy makers.

\section{Urban Food Insecurity and their interactions with health problems}

Dietary diversity, e.g., the number of food and food groups consumed over a set period of time, is considered a useful indicator of food security due to its strong correlation with nutritional status. Tacoli and colleagues ${ }^{[23]}$ compared the dietary diversity of individuals of higher and lower quintiles in urban and rural areas in several countries in sub-Saharan Africa and concluded that in both areas income plays a critical role.

According to Kennedy ${ }^{[28]}$, urban residents with low in- da mãe, porque dela depende a utilização mais ou menos eficiente (do ponto de vista do cuidado infantil) dos rendimentos e dos serviços públicos ${ }^{[17]}$.

Os processos de urbanização estão interligados com a transição nutricional, nomeadamente porque existe uma maior facilidade de acesso a alimentos de pouca qualidade nutricional a preços reduzidos, o que provoca alteração dos padrões alimentares, potenciando o aumento de doenças não transmissíveis. Além disso, este tipo de alimentos é, por norma, rico em hidratos de carbono complexos, gordura, açúcar, colesterol e pobre em fibra e vitaminas ${ }^{[21,22]}$.

Uma das principais questões da insegurança alimentar em contexto urbano prende-se com o facto de os residentes urbanos terem de comprar a maioria dos alimentos que consomem, ao contrário do que acontece em áreas rurais, onde as pessoas podem produzir sua própria comida ${ }^{[8]}$.

A segurança alimentar urbana é, portanto, muito dependente das condições monetárias, tornando as questões laborais e de acesso a rendimentos um pré-requisito fundamental para garantir a segurança alimentar em áreas urbanas. Esta situação é agravada pelo facto de em muitas cidades em África uma percentagem considerável de residentes depender de actividades informais e ocasionais que apenas garantem rendimentos, baixos, incertos e irregulares ${ }^{[23]}$. Segundo $\mathrm{Chen}^{[24]}$ nos países de baixa renda o emprego informal contribui para metade a três-quartos de todo o emprego não agrícola.

A disponibilidade de alimentos em contexto urbano é em grande medida determinada pela oferta de alimentos que chegam às cidades ${ }^{[23]}$.

Há estudos que vêm apontando para as especificidades da insegurança alimentar urbana, com especial atenção para a necessidade de promover condições para obter rendimentos por parte dos agregados familiares e acessibilidade de alimentos em contexto urbano. Ou seja, devido à insegurança alimentar em áreas urbanas emerge uma espiral de pobreza ${ }^{[8]}$.

As alterações rápidas de urbanização tiveram um impacto nutricional considerável em muitos países de baixa e média renda, contribuindo para as alterações dos padrões alimentares praticados ${ }^{[25]}$.

No âmbito da Estratégia de Segurança Alimentar e Nutricional, aprovada em 2012, a FAO está a trabalhar com a Comunidade de Países de Língua Portuguesa (CPLP), com o objectivo de alcançar uma "comunidade livre de fome". A insegurança alimentar afecta actualmente cerca de 28 milhões de pessoas nos países da CPLP, que tem um total de 250 milhões de pessoas ${ }^{[11]}$.

Além dos aspectos relacionados com a qualidade e a quantidade de alimentos, vários autores mencionam outros factos como a angústia psicológica (por exemplo, 
comes and a substantial proportion of rural residents share similar challenges to purchase enough food to ensure a healthy diet.

However, residents of urban areas have to deal with additional constraints which affect food safety. In particular, those relating to other dimensions of urban poverty that are not related to their low income. Diarrhoeal diseases are a good indicator of overall environmental hygiene and food safety, and in many cases are linked to malnutrition. The higher prevalence of episodes of diarrhoea among low income urban populations is closely related to unhealthy living environments. In informal (housing) settlements, the lack of water and clean toilets, often extreme overcrowding, and open sewers and stagnant water provide an exposure to pathogens, which are also transmitted by flies, mosquitoes and rats ${ }^{[28]}$.

Several studies have shown positive associations between food insecurity, incapacity to purchase food in quantity and quality, and chronic diseases such as hypertension, hyperlipidemia and diabetes, including both self-reported and laboratory data ${ }^{[29-31]}$. There is also some evidence that food insecurity is related to risk factors for cardiovascular diseases ${ }^{[30,32]}$.

Both food insecurity and obesity may be caused by multiple factors, which include low income levels and the consequent restriction on access to food with higher nutritional quality, as well as the adoption of more sedentary lifestyles, with a consequent imbalance between consumption and energy spending ${ }^{[25]}$. Food insecurity is also related to the condition of being overweight or obese, but these results are more consistent among women than among men and children ${ }^{[33,34]}$

There is evidence to the effect that sodium intake above recommended levels (eating habits), body weight, and possibly stress may be important predictors of hypertension ${ }^{[35-38]}$.

Studies conducted mainly in the USA present correlations between health status and food insecurity, including increased depression ${ }^{[39]}$ and nutritional inadequacies in adults ${ }^{[40,41]}$, and psychosocial ${ }^{[42,43]}$ and physical ${ }^{[21,22]}$ development problems in children.

Finally, people involved in food insecurity situations can also be more likely to delay taking necessary medications and the use of health care, prioritising instead basic needs ${ }^{[44]}$.

\section{Challenges in the study of social determinants of food insecurity}

One of the biggest challenges in the study of social de- preocupação sobre não ter o suficiente para comer) e perturbações sociofamiliares (por exemplo, recorrer a formas socialmente inaceitáveis de obtenção de alimentos), que também são importantes dimensões da insegurança alimentar ${ }^{[26,27]}$. Todos estes exemplos constituem potenciais impactos directos e/ou indirectos sobre o estado de saúde das populações, devendo como tal merecer atenção por parte dos decisores políticos.

\section{Insegurança Alimentar Urbana e suas interacções com problemas de saúde}

A diversidade dietética, ou seja, o número de alimentos e grupos de alimentos consumidos durante um período de tempo definido, é considerado um indicador útil da segurança alimentar devido à sua forte correlação com o estado nutricional. Tacoli e colegas ${ }^{[23]}$ compararam a diversidade da dieta dos indivíduos de quintis mais altos e mais baixos em áreas rurais e urbanas em vários países da África subsaariana e concluíram que em ambas as áreas o rendimento desempenha um papel crítico. Segundo Kennedy ${ }^{[28]}$ os compradores de alimentos, os residentes urbanos com baixos rendimentos e uma proporção substancial de residentes rurais partilham desafios semelhantes para conseguir alimentos suficientes para garantir uma dieta saudável.

No entanto, os residentes em contextos urbanos têm de lidar com restrições adicionais que afectam a sua segurança alimentar. Nomeadamente, os que se relacionam com outras dimensões da pobreza urbana que não estão relacionadas com o não-rendimento. As doenças diarreicas são um bom indicador da higiene ambiental global e da segurança alimentar, e em muitos casos estão ligados à desnutrição. A maior prevalência de episódios de diarreia entre as populações urbanas com baixos rendimentos está intimamente relacionada com ambientes de vida pouco saudáveis. Em bairros informais, a falta de água e instalações sanitárias limpas, muitas vezes uma superlotação extrema, esgotos a céu aberto e águas estagnadas proporcionam uma exposição a agentes patogénicos, que também são transmitidos por pragas como moscas, mosquitos e ratos ${ }^{[28]}$.

Vários estudos têm demonstrado associações positivas entre a insegurança alimentar, no sentido de incapacidade de compra de alimentos em quantidade e em qualidade, e as doenças crónicas como a hipertensão, hiperlipidemia e a diabetes, incluindo tanto dados autodeclarados como dados laboratoriais ${ }^{[29-31]}$. Há ainda alguma evidência de que a insegurança alimentar está relacionada a factores de risco de doenças cardio vasculares ${ }^{[30,32]}$.

Tanto a insegurança alimentar como a obesidade po- 
terminants and their relationship with food insecurity relates to the question: how to measure access to food? A recent international meeting on the measurement and assessment of food deprivation concluded that there is still no "perfect single measure that captures all aspects of food insecurity"[15].

The most extreme poverty is obvious, and there is no need of accurate measures designed to recognize it ${ }^{[15,45]}$. But not everything in poverty is so simple to measure, analyse, and understand when we move away from the extreme conditions. The Sen comment ${ }^{[45]}$ is also relevant to the study of food insecurity. Some families who are experiencing food insecurity do not face hunger immediately, and others who are in a desperate situation, for example from the point of view of access to food, can be a challenge in terms of studies as well as in the design of public interventions.

The challenges to study the social determinants of food insecurity in urban areas and their interactions with the health condition of the population open an important space for this line of research, a more necessary opportunity when we know the importance of informing the priorities and policy options and public health interventions on robust evidence.

Of all reflection undertaken within this text, the importance of ensuring better social, economic, labour and environmental conditions to the residents in urban contexts seems unquestionable, knowing the potential positive impact on health outcomes.

\section{Conflict of interests}

The authors declare that there are no financial and/or personal relationships that could be viewed as presenting a potential conflict of interests. dem advir de múltiplos factores, onde se inclui o baixo nível de rendimento e consequente restrição ao acesso a alimentos com maior qualidade nutricional, bem como a adoção de estilos de vida mais sedentários, com consequente desequilíbrio entre o consumo e o gasto energético ${ }^{[25]}$. A insegurança alimentar também se relaciona com excesso de peso ou obesidade, mas estes resultados são mais consistentes entre as mulheres do que entre os homens e crianças ${ }^{[33,34]}$.

Existe evidência segundo a qual a ingestão de sódio acima do recomendado (hábitos alimentares), o peso corporal e, possivelmente, o stress poderão ser importantes preditores de desenvolvimento da hipertensão ${ }^{[35-38]}$

Estudos realizados sobretudo nos EUA apresentam correlações entre o estado de saúde e a insegurança alimentar que incluem o aumento da depressão ${ }^{[39]}$ e inadequações nutricionais em adultos ${ }^{[40,41]}$, e problemas de desenvolvimento psicossocial ${ }^{[42,43]}$ e físico ${ }^{[21,22]} \mathrm{em}$ crianças.

E, finalmente, pessoas envolvidas em situações de insegurança alimentar também podem ser mais propensas a adiar a toma de medicamentos necessários e de cuidados médicos, priorizando as necessidades básicas ${ }^{[44]}$.

\section{Desafios no estudo dos determinantes sociais da insegurança alimentar}

Um dos maiores desafios no estudo dos determinantes sociais e sua relação com a insegurança alimentar prende-se com a questão: como medir o acesso à alimentação?

De facto, num recente encontro internacional sobre a medição e avaliação da privação alimentar concluiu-se que não existe ainda uma "medida única perfeita que capte todos os aspectos da insegurança alimentar ${ }^{[15]}$.

As condições de pobreza mais extrema são óbvias, não são precisas medidas elaboradas para reconhece$-\mathrm{la}^{[15,45]}$. Mas nem tudo nas condições de pobreza é tão simples de medir, analisar e compreender, quando nos afastamos das condições extremas. A observação de Sen ${ }^{[45]}$ é também relevante para o estudo da insegurança alimentar. Algumas famílias que estão a viver uma experiência de insegurança alimentar mas não enfrentam a fome imediatamente, e outros que estão em situação desesperada por exemplo do ponto de vista do acesso aos alimentos, podem constituir um desafio em termos dos estudos, mas também no delineamento de intervenções públicas.

Os desafios ainda existentes para estudar os determinantes sociais da insegurança alimentar no espaço urbano e suas interacções com a condição de saúde das populações abrem um espaço importante para esta linha 
de investigação, uma opção tanto mais necessária quando se sabe da importância de basear as prioridades e opções políticas e intervenções de saúde pública em evidência robusta.

De toda a reflexão empreendida, parece inquestionável a importância de garantir melhores condições sociais, económicas, laborais e ambientais com potencial impacto positivo nos resultados de saúde dos residentes em contextos urbanos.

\section{Conflito de Interesses}

Os autores declaram não existir qualquer relação pessoal ou financeira que possa ser entendida como representando um potencial conflito de interesses. 


\section{References/ Referências}

1. WHO | Food Security [Internet]. WHO. 2016. Available from: http://www.who.int/ trade/glossary/story028/en/

2. Buss PM, Pellegrini Filho A. A saúde e seus determinantes sociais. Physis Rev Saúde Coletiva. 2007 Apr;17(1):77-93.

3. Oliveira MJI, Espirito Santo E. A relação entre os determinantes sociais da saúde e a questão social. Cad Saúde E Desenvolv. 2013;2(2):7-24.

4. Gunning-Schepers LJ. Models: instruments for evidence based policy. J Epidemiol Community Health. 1999 May;53(5):263.

5. Campino ACC. Aspectos sócio-econômicos da desnutrição no Brasil. Rev Saúde Pública. 1986 Feb;20(1):83-101.

6. Harris-Fry H, Azad K, Kuddus A, Shaha S, Nahar B, Hossen M, et al. Socio-economic determinants of household food security and women's dietary diversity in rural Bangladesh: a cross-sectional study. J Health Popul Nutr 2015;33(1).

7. Rome Declaration and Plan of Action. 1996. [cited 2016 May 12]. Available from: http://www.fao.org/docrep/003/w3613e/ w3613e00.

8. van der Merwe C. Key Challenges for Ensuring Food Security in South Africa's Inner Cities. Afr Inst South Afr. 2011;(36):1-7.

9. Rose D. Economic determinants and dietary consequences of food insecurity in the United States. J Nutr. 1999 Feb;129(2S Suppl):517S - 520S.

10. Barrett CB. Measuring Food Insecurity. Science. 2010. 12;327(5967):825-8

11. FAO. The State of Food Insecurity in the World 2015 [Internet]. Food and Agriculture Organization of the United Nations. 2015. Available from: http://www.fao.org/hunger/ glossary/en/

12. Jones SJ, Frongillo EA. Food insecurity and subsequent weight gain in women. Public Health Nutr. 2007;10(2):145-51.

13. Løvendal CR, Knowles M, Hori N. Understanding vulnerability to food insecurity: Lessons from vulnerable livelihood profiling. FAO. 2004;04-18.

14. Løvendal CR, Knowles M. Tomorrow's Hunger: A framework for analyzing vulnerability to food insecurity. FAO [Internet]. 2005;05-07. Available from: http://ieham. org/html/docs/Tomorrow's_Hunger.pdf

15. Webb P, Coates J, Frongillo EA, Rogers BL, Swindale A, Bilinsky P. Measuring household food insecurity: why it's so important and yet so difficult to do. J Nutr. 2006;136(5):1404S - 1408S.

16. The State of Food Insecurity in the World 2015 [Internet]. Food and Agriculture Organization of the United Nations. [cited 2016 May 12]. Available from: http://www. fao.org/hunger/glossary/en/

17. Segurança Alimentar Nutricional e o direito à saúde. 2011. Available from: http://dssbr. org/site/2011/08/seguranca-alimentar-nutricional-e-o-direito-a-saude/

18. Osmani SR. Evolving Views on Poverty: Concept, Assessment, and Strategy. Asian Development Bank; 2003. 46 p.
19. Government of Canada HC. ARCHIVED Discussion Paper on Household and Individual Food Insecurity [Health Canada, 2001]. 2002. Available from: http://www.hc-sc. gc.ca/fn-an/nutrition/pol/food_sec_entiresec_aliments_entier-eng.php

20. Carter MA, Dubois L, Tremblay MS. Place and food insecurity: a critical review and synthesis of the literature. Public Health Nutr. 2014;17(01):94-112.

21. Abrahams Z, Mchiza Z, Steyn NP. Diet and mortality rates in Sub-Saharan Africa: Stages in the nutrition transition. BMC Public Health. 2011;11(1):801.

22. Ziraba AK, Fotso JC, Ochako R. Overweight and obesity in urban Africa: A problem of the rich or the poor? BMC Public Health. 2009;9(1):465.

23. Tacoli C. Urban poverty, food security and climate change [Internet]. International Institute for Enverionment and Development; 2013 p. 1-4. (IIED Briefing Papers). Available from: http://pubs.iied.org/17149IIED. html

24. Chen M. Informality, poverty and gender: evidence from the Global South. In: In: The International Handbook of gender and Poverty: Concepts, research, policy. Chant, S. Cheltenham, UK: Edward Elgar; 2010.

25. Popkin BM. Global nutrition dynamics: the world is shifting rapidly toward a diet linked with noncommunicable diseases. Am J Clin Nutr. 2006;84(2):289-98.

26. Hamelin A-M, Beaudry M, Habicht J-P. Characterization of household food insecurity in Québec: food and feelings. Soc Sci Med 1982. $2002 ; 54(1): 119-32$.

27. Radimer KL, Radimer KL. Measurement of household food security in the USA and other industrialised countries. Public Health Nutr. 2002;5(6A):859-64.

28. Kennedy G. Food Security in the context of urban sub-Saharan Africa. FoodAfrica. Internet Paper for Food Security Theme. 2003.

29. Terrell A, Drew C, Vargas R. Is Food Insecurity is associated with chronic disease control? Ethn Dis. 2009;19:1-6.

30. Seligman HK, Laraia BA, Kushel MB. Food Insecurity Is Associated with Chronic Disease among Low-Income NHANES Participants. J Nutr. 2010;140(2):304-10.

31. Irving SM, Njai RS, Siegel PZ. Food Insecurity and Self-Reported Hypertension Among Hispanic, Black, and White Adults in 12 States, Behavioral Risk Factor Surveillance System, 2009. Prev Chronic Dis. 2014:18;11.

32. Parker ED, Widome R, Nettleton JA, Pereira MA. Food security and metabolic syndrome in U.S. adults and adolescents: findings from the National Health and Nutrition Examination Survey, 1999-2006. Ann Epidemiol. 2010;20(5):364-70.

33. Larson NI, Story MT. Food insecurity and weight status among U.S. children and families: a review of the literature. Am J Prev Med. 2011;40(2):166-73.
34. Eisenmann JC, Gundersen C, Lohman BJ, Garasky S, Stewart SD. Is food insecurity related to overweight and obesity in children and adolescents? A summary of studies, 1995-2009. Obes Rev Off J Int Assoc Study Obes. 2011;12(5):e73-83.

35. Poulter NR, Khaw KT, Hopwood BE, Mugambi M, Peart WS, Rose G, et al. The Kenyan Luo migration study: observations on the initiation of a rise in blood pressure. BMJ. 1990: 14;300(6730):967-72.

36. Steptoe A, Kivimäki M. Stress and Cardiovascular Disease: An Update on Current Knowledge. Annu Rev Public Health. 2013:18;34(1):337-54.

37. Rosenthal T, Alter A. Occupational stress and hypertension. J Am Soc Hypertens. 2012;6(1):2-22.

38. Noubiap JJN, Bigna JJR, Nansseu JRN. Low Sodium and High Potassium Intake for Cardiovascular Prevention: Evidence Revisited With Emphasis on Challenges in Sub-Saharan Africa. J Clin Hypertens. 2015;17(1):813.

39. Heflin CM, Siefert K, Williams DR. Food insufficiency and women's mental health: findings from a 3-year panel of welfare recipients. Soc Sci Med 1982. 2005 Nov;61(9):1971-82.

40. Rose D, Oliveira V. Nutrient intakes of individuals from food-insufficient households in the United States. Am J Public Health. 1997:87(12):1956-61.

41. Kirkpatrick SI, Dodd KW, Parsons R, Ng C, Garriguet D, Tarasuk V. Household Food Insecurity Is a Stronger Marker of Adequacy of Nutrient Intakes among Canadian Compared to American Youth and Adults. J Nutr. 2015;145(7):1596-603.

42. Slopen N, Fitzmaurice G, Williams DR, Gilman SE. Poverty, food insecurity, and the behavior for childhood internalizing and externalizing disorders. J Am Acad Child Adolesc Psychiatry. 2010;49(5):444-52.

43. Alaimo K, Olson CM, Frongillo EA. Food insufficiency and American schoolaged children's cognitive, academic, and psychosocial development. Pediatrics. 2001;108(1):44-53.

44. Kushel MB, Gupta R, Gee L, Haas JS. Housing instability and food insecurity as barriers to health care among low-income Americans. J Gen Intern Med. 2006;21(1):71-7.

45. Sen A. Poverty and famines: An essay on entitlement and deprivation. Oxford: Clarendon Press; 1981. p. vii. Oxford: Clarendon Press; 1981. vii. 